\title{
Attracting and retaining female chefs
}

\section{Charles Orido}

Charles is a chef and lecturer at Kenya Utalii College, Nairobi, Kenya. His research interests include inhospitable hospitality, culinary arts, human behaviour in the hospitality industry, and indigenous research. $\mathrm{He}$ holds a Certificate in Food Production (currently Culinary Arts) from Kenya Utalii College, a BA degree in Hospitality

Management from the University of Nairobi, Kenya, and a Master of International Hospitality Management (MIHM) from Auckland

University of Technology, New Zealand.

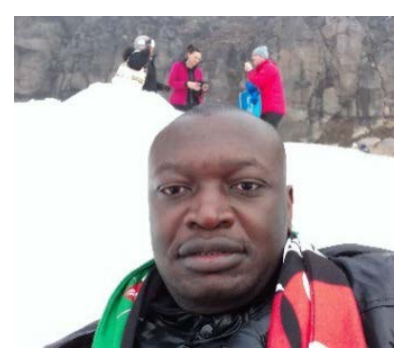

The chef profession is considered a challenging career, with female chefs seeming to be most affected. As such, it is rare to find female chefs occupying the coveted executive chef positions. The aim of this research was to establish if female chefs in Kenya encounter similar challenges to those experienced by female chefs elsewhere.

Previous research shows that female chefs encounter career challenges in hospitality organisations and hence they struggle to make it as chefs; for example, studies by Druckman [1] and Harris and Giuffre [2,3] in the United States, Murray-Gibbons and Gibbons [4] in the United Kingdom, as well as Zengeni et al. [5] in Zimbabwe. This article poses the important question: how can these challenges be overcome?

The study sought to make sense of the lived work experiences of Kenyan female chefs. Baum [6] recommends contextualised research methodologies to explore hospitality issues in non-Western countries. Moreover, Adelowo [7] asserts that lived experiences are better expressed through stories. Therefore, a qualitative approach was employed in this study where 15 chefs working in the Kenyan hospitality industry were interviewed [8]. Ten female chefs told stories of their workplace experiences while five male executive chefs recounted their experiences of working with female chefs.

Despite the different geographical, socio-cultural and economic factors between Kenya and other countries previously studied, female chefs expressed common challenges such as sexual harassment, gender discrimination, unsupportive attitudes towards pregnancy and an unhealthy work environment, as well as hierarchical kitchen structures that they believed discriminated against them. There was an indication of engrained patriarchal attitudes that limit the professional success of potential female chefs. Unfortunately, hospitality employers appeared to support the status quo; that is, a gendering of the chef's profession that privileges men and penalises women.

These findings suggest a trend that must worry hospitality employers. The highly competitive career structures and the male domination that discourages women from making a long-term career in the kitchen [2], coupled with stiff competition for scarce hospitality human resources, support the need to retain female chefs. Christensen and Rog [9] stress that employee retention strategies will only work if human resource managers are fully committed to creating a positive workplace culture that treats all employees equally, regardless of their gender or any other dimension of diversity.

In his study, Orido [8] suggests that the following measures may help to attract and retain female chefs. Firstly, employers should introduce personalised career 
development plans. For instance, a female chef who has attained postgraduate qualifications ought to be promoted and remunerated accordingly. This will not only retain female chefs but also enable them to further their career aspirations within the hospitality industry. Secondly, female chefs should be given the opportunity to fully participate at all levels of the kitchen hierarchy, thereby acquiring the necessary skills for promotion in the future to executive chef's positions. Additionally, it will encourage a clear career progression path within the kitchen hierarchy.

Hospitality employers must ensure that employment opportunities as well as employment terms and career progression are not dependant on a chef's gender, but on their qualifications and competencies. By investing in female chefs and, most importantly, keeping them safe from bullying at work, the hospitality industry will not only attract, but retain, these talented professionals in satisfying culinary careers.

If you would like to read the $\mathrm{PhD}$ thesis this research is based on you can access it here: http://hdl.handle.net/10292/10626

\section{Corresponding author}

Charles Orido can be contacted at: chaloridoh@gmail.com or corido@utalii.ac.ke

\section{References}

(1) Druckman, C. Why Are There No Great Women Chefs? Gastronomica 2010, 10, 24-31. https://doi.org/10.1525/gfc.2010.10.1.24

(2) Harris, D. A.; Giuffre, P. “The Price You Pay”: How Female Professional Chefs Negotiate Work and Family. Gender Issues 2010, 27, 27-52.

(3) Harris, D. A.; Giuffre, P. Taking the Heat: Women Chefs and Gender Inequality in the Professional Kitchen; Rutgers University Press: New Brunswick, NJ, 2015. https://books.google.co.nz/books?id=qTaACgAAQBAJ

(4) Murray-Gibbons, R.; Gibbons, C. Occupational Stress in the Chef Profession. International Journal of Contemporary Hospitality Management 2007, 19, 32-42. https://doi.org/10.1108/09596110710724143

(5) Zengeni, D. M. F.; Tendani, E.; Zengeni, N. The Absence of Females in Executive Chef Position in Zimbabwean Hotels: Case of Rainbow Tourism Group (RTG). Australian Journal of Business and Management Research 2013, 3, 1-18.

(6) Baum, T. Human Resources in Tourism: Still Waiting for Change? - A 2015 Reprise. Tourism Management 2015, 50, 204-212.

(7) Adelowo, A. The Adjustment of African Women Living in New Zealand: A Narrative Study; Ph.D. Thesis, Auckland University of Technology, 2012. http://aut.researchgateway.ac.nz/handle/10292/4601

(8) Orido, C. O. Challenges Faced by Female Chefs in the Kenyan Hospitality Industry: A Study through an African Oral Tradition of Storytelling; Ph.D. Thesis, Auckland University of Technology, 2017. http://hdl.handle.net/10292/10626

(9) Christensen, J.; Rog, E. Talent Management: A Strategy for Improving Employee Recruitment, Retention and Engagement within Hospitality Organizations. International Journal of Contemporary Hospitality Management 2008, 20, 743-757. 